Bangladesh J. Pl. Breed. Genet., 20(2) : 23-30, 2007

\title{
GENE ACTIONS OF TRAITS CONTRIBUTING TO LODGING RESISTANCE IN WHEAT (Triticum aestivum $\mathrm{L}$ )
}

\author{
Z. I. Sarker, A. K. M. Shamsuddin ${ }^{1}$, L. Rahman and R. Ara \\ Wheat Research Sub-station \\ Bangladesh Agricultural Research Institute \\ Rajbari, Dinajpur, Bangladesh
}

\begin{abstract}
Estimates of gene action for lodging related traits at Wheat Research Center during 1999-2002 in three crosses of wheat showed different genetic control of the traits among the crosses. For almost all traits, additive or dominance effects or both components were significant in either three- or six-parameter model, indicating that both additive and dominance gene effects were operative for different traits contributing to lodging resistance. Although duplicate type of epistasis was also observed for second internode breaking strength, plant height and spikes per plant and grain yield per plant once in different crosses, additive $\mathrm{x}$ additive epistasis along with additive gene action for the aforesaid traits would improve selection of the same in the segregating populations. The additive $\mathrm{x}$ dominance gene interaction for second internode length, diameter and wall thickness would be useful too for improvement of second internode breaking strength and consequently lodging resistance, as their inheritance and selection in segregating populations would be relatively easier than the traits controlled by completely non-additive genes. For duplicate type of epistasis biparental mating or recurrent selection followed by conventional selection is suggested.
\end{abstract}

Key words: Gene action, lodging resistance, internodes traits, grain yield, wheat (T. aestivum L).

\section{INTRODUCTION}

Lodging in wheat (Triticum aestivum $\mathrm{L}$ ) is a complex phenomenon, which is the result of the action and interaction of different plant characters. Several plant characters such as length, diameter and wall thickness of basal internodes, culm length, culm density, some anatomical, biochemical, physiological and mechanical characters are associated with lodging resistance. Stem lodging especially greatly depends upon the straw strength. Several mechanical devices have been developed by different workers and these measures are: breaking strength of straw, crushing strength, pulling resistance and bending resistance. Among these breaking strength got the highest importance (Pinthus, 1973).

Proper information on gene action of lodging and related traits as well as yield components is necessary for evaluation of any germplasm used in a breeding program. The choice of the breeding methodology depends upon the nature and magnitude of gene action.

\footnotetext{
${ }^{1}$ Department of Genetics and Plant Breeding, Bangladesh Agricultural University, Mymensingh; ${ }^{2}$ Associate Professor, Department of Entomology, Hajee Mohammad Danesh Science \& Technology University, Dinajpur, Bangladesh
} 
A breeding population having predominantly additive and additive $\mathrm{x}$ additive gene action is more responsive to selection than a population with predominantly non-additive gene action with epistasis of non-fixable nature. Estimation of gene effects from generation mean analysis is important in understanding the relative magnitude of gene action for the expression of a trait. Significant additive, dominance and epistatic gene effects do exist in most wheat populations and their presence may vary from cross to cross and from trait to trait in the same cross (Singh et al., 1984). In most cases, the value of the genetic parameters varied with parental genotype and growing environment. Most of the researches through out the world have been done on lodging in winter wheat and very few of them studied the genetic architecture of lodging resistance. In Bangladesh, no genetical study has been conducted on lodging resistance in wheat. Under the circumstances the present investigation was undertaken to study the gene actions of traits contributing to lodging resistance in three selected crosses of spring wheat.

\section{MATERIALS AND METHODS}

Gene action was studied in three selected crosses involving six parents (namely, Baviacora, Rayon, Seri 82, Sonora 64, Aghrani and Kheri) including their $F_{1}$ 's, $F_{2}$ 's and their back cross generations. The crosses were Baviacora x Kheri, Rayon x Agrani and Seri $82 \mathrm{x}$

Sonora 64. Among the parents, Baviacora, Rayon and Seri 82 have Rht $_{1}$ gene and Sonora 64 and Aghrani have $\mathrm{Rht}_{2}$ gene and Kheri did not have any major dwarfing genes (Sarker, 2003). The crosses and back crosses were made during 1999-2001 growing season. The parents, $F_{1}, F_{2}, B_{1}$ and $B_{2}$ of the crosses were sown on November 26, 2001 at Wheat Research Center Farm, Dinajpur. For a cross in each replicate, rows were 5.0m long and 17 rows per plot were distributed serially as follows: first two rows for $\mathrm{P}_{1}$, then one row for $\mathrm{F}_{1}$, then 8 rows for $F_{2}$, next two rows for $B_{1}$, next two rows for $B_{2}$ and last two rows for $P_{2}$. Seeds were sown $10 \mathrm{~cm}$ apart in rows with spacing of $25 \mathrm{~cm}$ between rows. The crosses were randomized within blocks and replicated three times. The crop was fertilized with NPK and S @ 100, 28, 40 and $20 \mathrm{~kg} / \mathrm{ha}$ (BARC, 1997), respectively. Two-thirds of the urea and the entire quantity of triple super phosphate, muriate of potash and gypsum were applied at final land preparation. The remaining one-third of urea was top dressed at 20 days after sowing (at crown root initiation stage) following the first irrigation. Mulching and weeding was done one time at 29 days after sowing. The second and third irrigations were given at 47 and 69 days after sowing, respectively. The number of plants selected for data recording per cross were 30 for $\mathrm{P}_{1}, 30$ for $\mathrm{P}_{2}, 30$ for $\mathrm{F}_{1}, 90$ for $\mathrm{B}_{1}, 90$ for $\mathrm{B}_{2}$ and 270 for $\mathrm{F}_{2}$. The plants were tagged randomly at heading stage and data were taken from these selected plants. Data were recorded on second internode length, diameter, wall thickness, breaking strength and unit section weight just after anthesis (termed as young stem traits) and spikes per plant, plant height, main shoot-weight and grains yield after harvest (termed as post harvest traits). To study the gene effects, data were first subjected to the scaling test of Mather and Jinks (1982) and joint scaling test of Cavalli (1952) to detect epistatic effect, if any. Then the data were analyzed for different components of generation means using additive dominance model as per Mather and Jinks (1982) and the digenic epistatic model described by Hayman (1958), Gamble (1962) and Jinks and Jones (1958) for the traits in which non-allelic interaction were detected. 


\section{RESULTS AND DISCUSSION Analysis of generation means}

The parents of the crosses differed significantly (expressed as $\mathrm{P}_{1}-\mathrm{P}_{2}$ for each cross) for most the young stem as well as post harvest traits studied including second internode breaking strength, plant height and main shoot weight which were the most important traits related to lodging resistance in wheat.

In the cross Baviacora $\times$ Kheri (Table 1), the parents differed significantly for all traits under study except second internode unit-stem weight and yield per plant. Significant positive heterosis over mid-parent in $\mathrm{F}_{1}$ was observed for plant height, main shoot weight and yield per plant, while negative heterosis was recorded for second internode breaking strength. Though significant positive heterosis over mid-parent in $\mathrm{F}_{2}$ was observed only for plant height but second internode wall thickness, second internode unit-stem weight and second internode breaking strength showed negative trend in $\mathrm{F}_{2}$.

In the cross Rayon x Aghrani (Table 1), the parents differed significantly for all traits except second internode wall thickness, plant height and spikes per plant. Significant positive heterosis over mid-parent in $\mathrm{F}_{1}$ was observed for second internode diameter and main shoot weight only. Whereas, in $\mathrm{F}_{2}$ generation significant negative heterosis over midparent was observed for spikes per plant and yield per plant.

In the cross Seri $82 \times$ Sonora 64 (Table 1), there existed significant variation for second internode length, second internode diameter, plant height, main shoot weight and yield per plant between the parents. Significant positive heterosis over mid-parent in $F_{1}$ was found for second internode length, plant height and main shoot weight only. Whereas significant positive heterosis over mid-parent was observed only for plant height but second internode diameter, spikes per plant and yield per plant showed negative heterosis in $\mathrm{F}_{2}$.

\section{Analysis of gene effects}

In cross Baviacora $\times$ Kheri 64 (Table 2), predominantly additive gene controlled second internode diameter and breaking strength. These traits were fitted in the threeparameter model, but remaining traits showed non-allelic gene interaction. Additive $\mathrm{x}$ dominance epistatic gene action controlled second internode length whereas second internode wall thickness was controlled by additive and additive $\times$ additive epistatic gene actions. The genetic control system of the second internode unit-stem weight was not much clear. It might be controlled by trigenic or higher order epistasis as the scale ' $C$ ' and joint scaling test were significant but no digenic epistatic parameters [i j l] were significant. Plant height was controlled by additive, dominance and dominance $\times$ dominance type gene actions. Spikes per plant were controlled by additive, dominance and all types of digenic epistatic gene effects except additive $\times$ dominance epistatic gene actions. Similarly additive, dominance and all types of digenic epistatic gene action controlled grain yield per plant except dominance $\times$ dominance epistatic gene effects. Main shoot weight was found to be regulated by additive $\times$ dominance and dominance $\mathrm{x}$ dominance type digenic epistasis.

In cross Rayon $\times$ Aghrani (Table 2), second internode diameter, internode unit-stem weight and main shoot weight were predominantly controlled by additive gene action. These traits were fitted in the three-parameter model but rest of the traits showed non-allelic gene interaction. Internode breaking strength were controlled by additive, dominance and additive $x$ additive and dominance $x$ dominance type epistatic gene action whereas additive $x$ dominance type epistasis was active on internode length. Dominance $\times$ dominance type 
epistatic gene action controlled second internode wall thickness. Grain yield per plant were controlled by additive, dominance and additive $\times$ additive epistatic gene actions. Spikes per plant were controlled by dominance and additive $\times$ additive epistatic gene effects. The gene action for plant height was not understandable as none of the scales or any of the components except [m] was significant.

Table 1. Mean (mean $\pm \mathrm{SE}$ ) of traits contributing to lodging resistance in different generations of three crosses of wheat

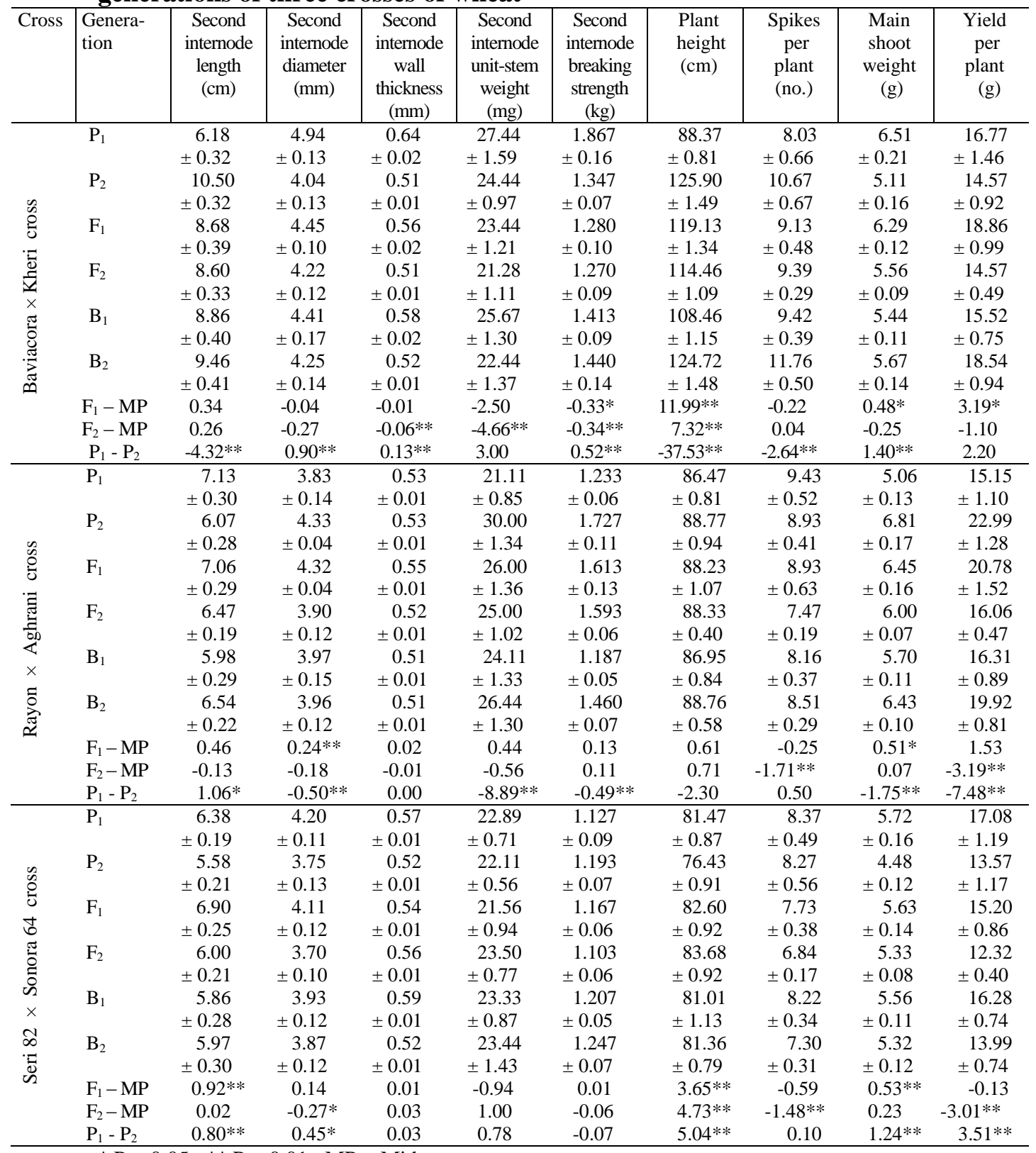

\footnotetext{
$* \mathrm{P}<0.05, * * \mathrm{P}<0.01, \mathrm{MP}=$ Mid parent
} 
Table 2. Gene effects for traits contributing to lodging resistance in three wheat crosses.

\begin{tabular}{|c|c|c|c|c|c|c|c|c|c|c|c|}
\hline Cross & Tests & $\begin{array}{l}\text { Para- } \\
\text { meter }\end{array}$ & $\begin{array}{l}\text { Second } \\
\text { internode } \\
\text { length } \\
(\mathrm{cm})\end{array}$ & $\begin{array}{c}\text { Second } \\
\text { internode } \\
\text { diameter } \\
(\mathrm{mm})\end{array}$ & $\begin{array}{l}\text { Second } \\
\text { internode } \\
\text { wall } \\
\text { thickness } \\
(\mathrm{mm})\end{array}$ & $\begin{array}{l}\text { Second } \\
\text { internode } \\
\text { unit-stem } \\
\text { weight } \\
\text { (mg) }\end{array}$ & $\begin{array}{l}\text { Second } \\
\text { internode } \\
\text { breaking } \\
\text { strength } \\
(\mathrm{kg})\end{array}$ & $\begin{array}{l}\text { Plant } \\
\text { height } \\
(\mathrm{cm})\end{array}$ & $\begin{array}{c}\text { Spikes } \\
\text { per } \\
\text { plant }(\#)\end{array}$ & $\begin{array}{c}\text { Main } \\
\text { shoot } \\
\text { weight } \\
(\mathrm{g})\end{array}$ & $\begin{array}{l}\text { Yield } \\
\text { per } \\
\text { plant } \\
(\mathrm{g})\end{array}$ \\
\hline \multirow{13}{*}{ 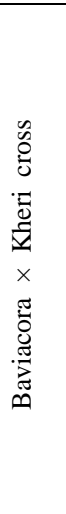 } & Scaling & $\mathrm{A}$ & $2.86 * *$ & -0.57 & -0.04 & 0.46 & -0.32 & $9.42 * *$ & 1.68 & $-1.92 * *$ & -4.59 \\
\hline & test & B & -0.26 & 0.01 & -0.03 & -3.00 & 0.25 & 4.41 & $3.72 *$ & -0.06 & 3.65 \\
\hline & & $\mathrm{C}$ & 0.36 & -1.00 & $-0.23 * *$ & $-13.64 *$ & -0.69 & 5.31 & 0.60 & $-1.96 * *$ & $-10.78 * *$ \\
\hline & Additive- & $\mathrm{m}$ & $6.10 * *$ & $4.05 * *$ & $0.42 * *$ & $14.84 * *$ & $0.98 *$ & $98.61 * *$ & $4.55^{*}$ & $5.83 * *$ & 5.83 \\
\hline & dominance & d & $-2.16 * *$ & $0.45^{* *}$ & $0.06 * *$ & 1.50 & $0.26 * *$ & $-18.76^{* *}$ & $-1.32 * *$ & $0.70 * *$ & 1.10 \\
\hline & & $\mathrm{h}$ & 7.42 & 0.28 & 0.23 & 17.16 & 0.86 & $42.87 * *$ & $14.78^{* *}$ & -1.54 & $21.93^{*}$ \\
\hline & $\begin{array}{l}\text { Joint } \\
\text { scaling test }\end{array}$ & $\chi^{2}$ & $9.88^{*}$ & 5.03 & $9.86^{*}$ & 7.51 & 4.41 & $11.89 * *$ & $11.56^{* *}$ & $37.08 * *$ & $19.98 * *$ \\
\hline & Epistatic & $\mathrm{m}$ & $8.60 * *$ & - & $0.51 * *$ & - & - & $114.46^{* * *}$ & $9.39 * *$ & $5.56 * *$ & $14.57 * *$ \\
\hline & model & $\mathrm{d}$ & -0.60 & - & $0.06 * *$ & - & - & $-16.26^{* *}$ & $-2.34 * *$ & -0.23 & $-3.02 * *$ \\
\hline & & $\mathrm{h}$ & 2.58 & - & 0.14 & - & - & $20.51 * *$ & $4.58 *$ & 0.46 & $13.03 * *$ \\
\hline & & $\mathrm{i}$ & 2.24 & - & $0.15^{*}$ & - & - & 8.52 & $4.80 * *$ & -0.02 & $9.84 * *$ \\
\hline & & $\mathrm{j}$ & $1.56^{*}$ & - & -0.00 & - & - & 2.50 & -1.02 & $-0.93 * *$ & $-4.12 * *$ \\
\hline & & 1 & -4.84 & - & -0.08 & - & - & $-22.35^{*}$ & $-10.20^{* *}$ & $2.00^{*}$ & -8.90 \\
\hline \multirow{13}{*}{ 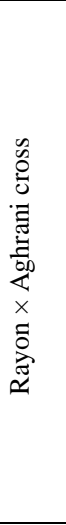 } & Scaling & $\mathrm{A}$ & $-2.23 * *$ & -0.21 & $-0.06^{*}$ & 1.11 & $-0.47 * *$ & -0.80 & -2.04 & -011 & -3.67 \\
\hline & test & B & -0.05 & $-0.73 * *$ & $-0.07 *$ & -3.12 & -0.42 & 0.52 & -0.84 & -0.40 & -3.93 \\
\hline & & $\mathrm{C}$ & -1.44 & $-1.20 *$ & -0.08 & -3.11 & 0.19 & 1.62 & $-6.34 * *$ & -0.77 & $-15.82 * *$ \\
\hline & Additive- & $\mathrm{m}$ & $7.44 * *$ & $3.82 * *$ & $0.58 * *$ & $24.45^{* *}$ & $2.56^{* *}$ & $89.52 * *$ & $5.72 * *$ & $5.68^{* *} *$ & $11.03 * *$ \\
\hline & model & d & $0.53 * *$ & $-0.25 * *$ & 0.00 & $-4.44 * *$ & $-0.25 * *$ & -1.15 & 0.25 & $-0.88 * *$ & $-3.74 * *$ \\
\hline & & $\mathrm{h}$ & -3.50 & -0.18 & -0.20 & 0.63 & $-2.92 * *$ & -3.47 & 3.79 & 0.52 & 10.37 \\
\hline & $\begin{array}{l}\text { Joint } \\
\text { scaling test }\end{array}$ & $\chi^{2}$ & $10.49^{*}$ & $14.62 * *$ & $8.12^{*}$ & 1.42 & $17.46^{* * *}$ & 0.80 & $19.92 * *$ & 3.06 & $18.55^{* *}$ \\
\hline & Epistatic & $\mathrm{m}$ & $6.47 * *$ & $3.90 * *$ & $0.52 * *$ & - & $1.59 * *$ & - & $7.47 * *$ & - & $16.06^{* * *}$ \\
\hline & model & d & -0.56 & 0.01 & 0.00 & - & $-0.27 * *$ & - & -0.35 & - & $-3.61 * *$ \\
\hline & & $\mathrm{h}$ & -0.38 & 0.50 & -0.03 & - & $-0.95 * *$ & - & $3.21 *$ & - & $9.75^{* *}$ \\
\hline & & $\mathrm{i}$ & -0.84 & 0.26 & -0.05 & - & $-1.08 * *$ & - & $3.46^{* *}$ & - & $8.22 * *$ \\
\hline & & $\mathrm{j}$ & $-1.09 *$ & 0.26 & 0.00 & - & -0.03 & - & -0.60 & - & 0.13 \\
\hline & & 1 & 3.12 & 0.68 & $0.17 *$ & - & $1.97 * *$ & - & -0.58 & - & -0.62 \\
\hline \multirow{13}{*}{ 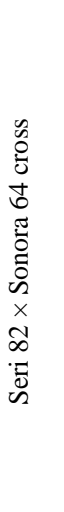 } & Scaling & $\mathrm{A}$ & $-1.56^{*}$ & -0.45 & $0.09 * *$ & 2.21 & 0.12 & -2.05 & -0.34 & -0.23 & 0.28 \\
\hline & test & B & -0.54 & -0.12 & -0.03 & 3.21 & 0.13 & 1.69 & -1.40 & 0.53 & -0.79 \\
\hline & & $\mathrm{C}$ & -1.76 & $-1.37 * *$ & 0.09 & 5.88 & -0.24 & $11.62 * *$ & $-4.74 * *$ & -0.14 & $-11.77 * *$ \\
\hline & Additive- & $\mathrm{m}$ & $6.32 * *$ & $3.17 * *$ & $0.56^{* *}$ & $22.96 * *$ & $0.66^{*}$ & $90.93 * *$ & $4.64 * *$ & $4.66^{* * *}$ & 4.06 \\
\hline & model & d & $0.40 * *$ & $0.22 * *$ & 0.01 & 0.39 & -0.03 & $2.52 * *$ & 0.05 & $0.62 * *$ & $1.76^{*}$ \\
\hline & & $\mathrm{h}$ & -1.86 & 1.16 & 0.01 & 3.56 & 1.25 & -20.67 & 5.71 & 1.71 & $21.89 * *$ \\
\hline & $\begin{array}{l}\text { Joint } \\
\text { scaling test }\end{array}$ & $\chi^{2}$ & 7.32 & $8.94 *$ & $12.96^{* *} *$ & 3.40 & 3.28 & $9.31 *$ & $19.82 * *$ & 4.85 & $26.65^{* *}$ \\
\hline & Epistatic & $\mathrm{m}$ & - & $3.70 * *$ & $0.56 * *$ & - & - & $83.68 * *$ & $6.84 * *$ & - & $12.32 * *$ \\
\hline & model & $\mathrm{d}$ & - & 0.06 & $0.07 * *$ & - & - & 0.65 & $0.92 *$ & - & $2.29 *$ \\
\hline & & $\mathrm{h}$ & - & 0.93 & -0.02 & - & - & -8.33 & $3.09 *$ & - & $11.14 * *$ \\
\hline & & $\mathrm{i}$ & - & 0.80 & -0.03 & - & - & $-11.98 * *$ & $3.68 * *$ & - & $11.26^{* * *}$ \\
\hline & & $\mathrm{j}$ & - & -0.16 & $0.06 * *$ & - & - & -1.87 & 0.87 & - & 0.54 \\
\hline & & 1 & - & -0.23 & -0.03 & - & - & 12.34 & -2.62 & - & $-10.75^{*}$ \\
\hline
\end{tabular}

$* \mathrm{P}<0.05, \quad$ ** $\mathrm{P}<0.01$, level of probability

In cross Seri $82 \times$ Sonora 64 (Table 2), second internode length and main shoot weight were predominately controlled by additive gene action. These traits fitted in the three-parameter model but rest of the traits showed non-allelic gene interaction. The second 
internode diameter was predominantly controlled by additive gene and trigenic or higher order epistasis as the scale ' $C$ ' and joint scaling test were significant but no digenic epistatic parameters $[i, j, 1]$ were significant. The second internode wall thickness expressed additive and additive $\mathrm{x}$ dominance type digenic epistatic gene actions. Plant height expressed additive $x$ additive epistatic gene effect. Grain yield per plant were controlled by additive, dominance gene effects as well as by additive $x$ additive and dominance $x$ dominance epistatic gene actions. Spikes per plant were controlled by additive, dominance and additive $\times$ additive epistatic gene actions. The genetic control system of the second internode unit-stem weight and internode breaking strength were not clear as none of the scales or any of the components except [m] was significant.

For almost all traits investigated, the additive or dominance or both components were significant in either three- or six-parameter models (Table 2). These results indicated that both additive and dominance gene effects were operative for different traits related to lodging as well as yield but that their level of significance and magnitude changed with each cross. Dolinski et al. (1996a, 1996b) reported epistatic gene action for inheritance of length of the second internode and stem diameter. Zalewski et al. (1999a, 1999b) found that stem length, average outer diameter of the stem and average stem wall thickness were conditioned by additive gene action.

It was noticed that the dominance $x$ dominance interaction effect was a major component of epistasis and significant for most of the traits in different crosses. In respect of magnitude and significance level, additive $x$ additive gene interaction followed dominant $x$ dominant type epistasis. On the contrary, the additive $x$ dominance interaction effect was found to be a minor component of epistasis as its magnitude was lowest in the majority of cases. The dominance $\times$ dominance type epistasis exerted the greatest influence upon most of the traits in all crosses, where evidence of epistasis was found present. Similar results were corroborated by the findings of Singh and Singh (1978) while studying five traits in three wheat crosses.

When both dominance and dominance $\mathrm{x}$ dominance epistasis were significant and had an opposite sign that indicates duplicate epistasis. Such duplicate epistasis was found for plant height and spikes per plant in cross Baviacora $\times$ Kheri. Such duplicate epistasis was also found for the second internode breaking strength in cross Rayon $\times$ Aghrani, for yield per plant in cross Seri $82 \times$ Sonora 64. Dhanda and Sethi (1996) reported duplicate epistasis for all traits they studied in nine generations. Delayed selection (Sharma and Sharma, 1995) or selection after biparental intermating (Misra et al., 1994) would be more effective to get a good response in such cases. Amawate and Behl (1995) suggested that duplicate epistasis might restrict the expression as well selection of a trait in early segregating generations. The selection in early generations of wheat crosses would not be effective for want of fixable components of variation. Such gene effects can however be exploited by intermating the selected segregants and delaying the selection to the advanced generations (Jindal et al., 1993).

Inadequacy of the additive-dominance model and significant epistatic gene interactions for plant height, tillers per plant and yield per plant were also reported by Jindal et al. (1993). The additive $\times$ additive type epistasis played second important role regarding its magnitude and significance level along with dominance gene action effecting for most of the traits. Bhullar et al. (1979) reported additive gene action for tillers per plant, while others (Jain and Singh, 1976; Sayeed, 1978; Sharma et al., 1996) found predominance of non- 
additive gene action including different types of epistasis for inheritance of the trait. Bhatt (1972) reported additive gene action for plant height, while Chapman and McNeal (1971) reported the involvement of dominance and epistasis for this trait, in addition to additive genetic effect. Epistasis of duplicate type was found for plant height by Law et al. (1978) in winter wheat.

However, the role of additive $\times$ additive epistasis along with additive gene action for the aforesaid traits would be important for inheritance of the traits and would make easier selection of the traits in the early segregating populations. Similarly, the additive $x$ dominance gene interaction for some traits (internode length, internode wall thickness etc.) those are contributing to internode breaking strength and might be useful too for improvement of internode breaking strength consequently lodging resistance, as their inheritance and selection in segregating populations would be relatively easier compared to traits controlled by duplicate epistatic gene action. Biparental intermating between selected recombinants as well as mating of selected segregants between crosses in early segregating generations or recurrent selection generates more heritable variation. In case of duplicate type of non-allelic interaction biparental intermating or recurrent selection followed by conventional selection method is suggested to be more appropriate for the improvement of the traits related to lodging resistance.

\section{REFERENCES}

Amawate, J. S. and P. N. Behl. 1995. Genetic analysis of some quantitative components of yield in bread wheat. Indian J. Genet. $55: 120-125$.

BARC. 1997. Fertilizer Recommendation Guide. Published by Bangladesh Agril. Res. Council, Dhaka, Bangladesh. P-44.

Bhatt, G. M. 1972. Inheritance of heading date, plant height, and kernel weight in two spring wheat crosses. Crop Sci. 12 : 95-98.

Bhullar, G. S., K. S. Gill and A. S. Khehra. 1979. Combining ability analysis over $\mathrm{F}_{1}-\mathrm{F}_{5}$ generations in diallel crosses of bread wheat. Theor. Appl. Genet. 55 : 77-80.

Cavalli, L. L. 1952. An analysis of linkage in quantitative inheritance, In "Quantitative Inheritance", Eds, E. C. R. Reeve and C. H. Waddington, HMSO, London. pp. 135144.

Chapman, S. R. and F. H. McNeal. 1971. Gene action for yield components and plant height in a spring wheat cross. Crop Sci. $11: 384-386$.

Dhanda, S. S. and G. S. Sethi. 1996. Genetics and interrelationships of grain yield and its related traits in bread wheat under irrigated and rainfed conditions. Wheat Information Service. $83: 19-27$.

Dolinski, R., W. Lonc and D. Zalewski. 1996a. Diallel analysis of the stem mechanical properties determining lodging resistance of winter wheat. Biuletyn Instytutu Hodowli i Aklimatyzacji Roslin. 200 : 245-250.

Dolinski, R., W. Lonc and D. Zalewski. 1996b. Gene action determining the geometric features of stems and some elements of yield related to lodging resistance of winter wheat. Biuletyn Instytutu Hodowlii Aklimatyzacji Roslin. 200 : 251-257.

Gamble, E. E. 1962. Gene effects in corn (Zea mays, L.) I. Separation and relative importance of gene effects for yield. Canadian J. Plant Sci. $42: 339-348$.

Hayman, B. I. 1958. The separation of epistatic from additive and dominance variation in generation means. Heredity $12: 271-390$. 
Jain, R. P. and R. B. Singh. 1976. Diallel cross among sixteen varieties of bread wheat (Triticum aestivum L.) Studies on yield and its components. Egypt J. Genet. Cytol. 5: 98-108.

Jindal, Y, R. K. Behl and K. P. Singh. 1993. Gene effects for grain yield and its components in two wheat crosses. Inter. J. Trop. Agric. 11 (2) : 123-126.

Jinks, J. L. and R. M. Jones. 1958. Estimation of the components of heterosis. Genetics $43: 223-234$.

Law, C. N., J. W. Snape and A. J. Worland. 1978. The genetical relationship between height and yield in wheat. Heredity $40: 133-151$.

Mather, K. and J. L. Jinks. 1982. Biometrical Genetics. The Study of Continuous Variation. $3^{\text {rd }}$ Edn. Chapman and Hall Ltd. London.

Misra, S. C., V. S. Rao, R. N. Dixit, V. D. Surve and V. P. Patil. 1994. Genetic control of yield and its components in bread wheat. Indian J. Genet. 54 : 77-82.

Pinthus, M. J. 1973. Lodging in wheat, barley, and oats : The phenomenon, its causes, and preventive measures. Advances in Agron. 25 : 209-263.

Sarker, Z. I. 2003. Inheritance of lodging resistance related to dwarfing gene effects in bread wheat. Ph.D. Thesis, Dept. of Genet. and Plant Breed., BAU, Mymensingh, Bangladesh.

Sayeed, H. I. 1978. Inheritance of five quantitative characters of bread wheat. Theor. Appl. Genet. $52:$ 73-76.

Sharma, P. K., D. K. Grag and P. C. Sharma. 1996. Genetic characterization of some quantitative characters in wheat. Indian J. Genet. 56 (3) : 281-284.

Sharma, S. N. and R. K. Sharma. 1995. Genetic architecture of harvest index in tetraploid wheat (T. durum Desf.). Indian J. Genet. 55 (3) : 233-237.

Singh, G., G. S. Nanda and K. S. Gill. 1984. Inheritance of yield and its components in five crosses of spring wheat. Indian J. Agric. Sci. 54 (11) : 943-949.

Singh, S. and R. B. Singh. 1978. A study of gene effects in three wheat crosses. J. Agric. Sci. $91: 9-12$.

Zalewski, D., W. Lonc and R. Dolinaki. 1999a. Diallel analysis of stem mechanical properties determining lodging resistance in winter wheat. Biuletyn Instytutu Hodowli i Aklimatyzacji Roslin. 212 : 23-30.

Zalewski, D., W. Lonc and R. Dolinaki. 1999b. Mode of action of genes determining geometric properties of the stem and some yield components related to lodging resistance of winter wheat. Biuletyn Instytutu Hodowlii Aklimatyzacji Roslin. 212: $31-39$ 